\title{
PEDAGOGY
}

\section{SUBSTANTIATION OF THE METHODOLOGICAL EXPEDIENCY TO USE THE METHOD OF WRITING ESSAYS ON SOCIAL AND PEDAGOGICAL TOPICS}

\author{
Opaliuk T. L., Doctor of Pedagogical Sciences, Associate Professor of the Department of Social \\ Pedagogy and Social Work of Kamianets-Podilskyi National University named after Ivan Ogienko, \\ Kamianets-Podilskyi, Ukraine.
}

DOI: https://doi.org/10.31435/rsglobal_sr/28022020/6954

\section{ARTICLE INFO}

Received 23 December 2019

Accepted 10 February 2020

Published 28 February 2020

\section{KEYWORDS}

method of essay writing, methodological support, social reflection, personal orientation, interactivity, social competence.

\begin{abstract}
The article presents an attempt to provide a comprehensive substantiation of the feasibility of using the method of writing an essay on social and pedagogical topics during the teacher training process. Based on the interpretation of the method essence, its functional purpose in philosophical and linguistic literature as well as works on literary studies, they determine the adaptation foundations regarding the specific features of the effective use of the essay method in the educational process, pedagogy as an academic discipline. Specific examples are used to demonstrate the priorities of the essay method when developing social competence in particular and the social reflection of the future teacher in general. They mention the strengthening of the roles of the student's activities related to self-education and self-assessment, development of their creative reflective thinking, and the strengthened ability to make effective decisions regarding a burning problem of both professional and social significance.
\end{abstract}

Citation: Opaliuk T. L. (2020) Substantiation of the Methodological Expediency to Use the Method of Writing Essays on Social and Pedagogical Topics. Science Review. 2(29). doi: 10.31435/rsglobal_sr/28022020/6954

Copyright: (C) 2020 Opaliuk T. L. This is an open-access article distributed under the terms of the Creative Commons Attribution License (CC BY). The use, distribution or reproduction in other forums is permitted, provided the original author(s) or licensor are credited and that the original publication in this journal is cited, in accordance with accepted academic practice. No use, distribution or reproduction is permitted which does not comply with these terms.

"This huge world is the mirror in which we need to look to know ourselves to the end" Michel de Montaigne, founder of the essay genre

"Essay is a way to tell the world through yourself and about yourself with the help of the world" Vladimir Nabokov

The basic algorithms used to justify the need to intensify the search for person-oriented, creative methods and technologies for the professional training of future teachers are associated with peculiarities of the dynamic, multi-vector and contradictory time, respectively, specific features of the sociocultural space, and in its context, the educational space, which determines the need for mobile, creative specialists, who are good at self-realization under ever-changing conditions.

Tendencies towards personal orientation and, as a result, towards the individualization of modern social relations, which are objectified in the education of all levels and directions, determine the processes of searching for adequate forms and methods of educational activities, especially when it comes to the vocational education system focused on the training of teachers to organize an innovative, competent educational activity among students over the long term, including its important component as social competence, actualizing the social and reflective activity.

In this context, interactive teaching methods, in particular the formation of the teacher's social competence, which are implemented both through external and internal interaction, interactive 
activity, communication and aim at enhancing educational and cognitive activity, developing creative potential of the student, productive critical thinking, are becoming especially relevant.

Methods of the mentioned level include essays (French - essai - "attempt, test, assay"), the main purpose of which is to present the results of the independent interpretation of a problem based on the integration of the processed educational material and personal experience of its comprehension through the prism of social realia that make up the life content of the student during their professional development with a projection on to the future teaching activity.

Essay, as a method, also as a learning method, is the subject of research interest for philosophers, literary critics, sociologists, psychologists, and educators. Different aspects of the problem are investigated by N. Khamitov, H. Rudenko, K. Shenderovsky, including problems of interpreting the nature of the method, its functional purpose in various spheres of activity with a particular emphasis on the educational sphere.

The philosophical interpretation of the functional purpose of essayism, and hence the method of essay, can be determined based on the viewpoint of Nazyp Khamitov, who interprets the essay philosophy as the philosophy that comprehends the reality in the harmony of the conceptual and imagination principles - in the sense related image. Therefore, the essay philosophizing appears to be incomplete and open, an aphoristic journal of an individual, affecting eternal problems of the man and the world rather than acute issues [3].

Additionally, the essay as a method that induces the subjective assessment of a particular problem, the activation of creative thinking and its suitable written representation, is interpreted by H. Rudenko. "The essay implies the expression of the author's point of view, personal subjective assessment for the subject of reasoning, provides an opportunity for non-standard (creative), distinctive coverage of the information; often, it is a conversation aloud, expression of emotions and imagery. It is also a free style with possible elements of improvisation, certain pathos, and irony. However, all this results in different interpretations of this type of written work, as well as various attempts to formalize it [1, p.15].

In the context of the rationale for using the essay, K. Shenderovsky points to the development of linguistic literacy, competence of its author. "The use of an essay contributes to a clearer and competent formulation of thoughts, it helps organize thoughts in a logical sequence, involves fluency in the language of terms and concepts, reveals the depth and breadth of educational material, teaches to use examples, quotes, necessary arguments related to a particular topic, allows for the comparison of facts, approaches and alternatives, formulation of conclusions, personal assessment" [4].

The purpose of the article is to find out the professional and educational, social and pedagogical, in its context - methodical rationale for using the method of writing essays on social and pedagogical topics, based on a comprehensive analysis of its nature and general functional purpose.

Representation of the basic material. The modernization of the national educational system, including vocational and pedagogical ones, takes place under the influence of the world tendencies related to the need to for the formation of an educational space, the environment that is supportive professionally and socially oriented (sociodidactic environment) as the basis for personal selfactualization of each individual, the formation of an individual trajectory of their professional development, based on personal characteristics, potential opportunities for development. The features of the competence-based education determine the need for searching not only the content, but also the forms and methods for the student's self-actualization, the formation of future professional activities on the basis of the "I-concept", its personality-centered methodology and style.

The philosophical interpretation of the phenomenon has found its variants of objectification in various spheres of activity, including educational and professional ones. Its use is associated with upto-date tendencies of education development, in particular, the provision of personality and competence based orientation, the formation of conditions for the student self-actualization, the contribution to the identification of an individual trajectory for the professional development in accordance with the capabilities of everyone.

According to K. Shenderovsky, "Individualization of modern social relationships and, as a result, individualization of modern vocational education are open for the application of new effective forms of activity, including an educational one. That is why the essay (a transformed, adapted, modified genre of literature) is gaining in popularity as a kind of the written independent work of the Ukrainian student, namely as a small reasoning composition with a free composition that expresses individual impressions, thoughts on a particular issue, problems, and consciously does not claim to be complete and exhaustive in interpreting the topic" [4, p.7]. 
Therefore, integrally in teaching, the essay contributes to the increased level of the personality-oriented education in general, the individualization of the trajectory for the student professional development, the formation of their social competence in particular, and it is also the subject of transformation, adaptation processes, and most importantly - optimization of interdisciplinary interaction at the content and procedural levels.

The essay is also understood as one of the effective methods of vocational and pedagogical education with a high potential of social and life creativity, and it is elaborated by means of strengthening the subjective understanding of problems, situations (an attempt of independent analysis, substantiation of a theoretical hypothesis, etc.). In terms of its form, the essay is defined as a small prose reasoning composition with a free structural and compositional organization. The essay has similar characteristics of a philosophical treatise, a reference paper, a scientific article, in literature - a composition, epic, lyric, pointing to the associative approach, verbalization of thinking, its imagery, personal orientation, the author's presentation of their personified vision of the image, problem, etc.

A social and pedagogical essay is of particular value in the professional development of the teacher, which a priori comprehends the future profession in the complex of its theoretical and practical foundations, integrated into the social and cultural space by correlating the objectively given educational information with individual reasoning regarding its nature through the prism of personal ideas and the experience of interpreting a specific issue, problem, and it does not involve a full coverage of their content.

Since the essay is an independent creative writing work, which is a form of the personality-oriented understanding of a given problem, it implements the functions related to the actual formation of professional competence, based on the "I-concept", resorting not only to self-determination in its context, but also to programming algorithms for searching answers to questions, solving problems, organizing activities. Within the educational activity, the essay actualizes such processes as analysis, synthesis, and creative application of knowledge about a specific professional, socially significant problem.

As part of the methodical rationale for using the method of writing social pedagogical essays, from the perspective of the above mentioned priorities, it is advisable to compare the educational works that are similar in the form of presentation, such as a reference paper (the information and reproductive system of education) and essay (personality-oriented, competence-based). When the primary goal of writing a reference paper is mainly the work with educational information (its selection, structuring, synthesis, conclusions) together with deepening of knowledge about a particular topic, the essay writing shifts the emphasis on the student's self-determination in its context, positioning the variant of its personal interpretation, which is implemented through integration, interaction of objectively defined educational (scientific) information with a personal concept and format of the worldview, linking such information to the life space, building associative flows of the comprehension of information through the prism of value priorities of the current social environment, personal experience of life. Under such conditions, a pedagogical essay naturally gains features of social orientation, without which there is no the student's personal self-determination.

It should be noted that it is not about the methods to replace the traditional forms of work with educational information, but about the rationale for their combination, since reference papers provide a rather effective way to form basic knowledge by means of actualizing the methods of working on literature sources, analyzing, comparing, systematizing information from various fields of knowledge, linking the theoretical material to the practical experience (as a rule, not personal, but presented in literature). If we talk about certain guiding templates in writing the above types of work, in the classical version, they are more formalized, their observance is perceived as quality criteria; in terms of innovation, they function as a recommendation and regulatory mechanisms, optimizing the methodological support for the process. The criteria are located in the plane of depth and awareness of the knowledge of the material to design an independent search for answers to questions, personal selfdetermination on the topic, without claiming its comprehensive interpretation. At the same time, the adequacy and validity of the theoretical basis, the substantiation of items, the reasoning of conclusions, the level of appealing to the personal life, social practice are evaluated.

It should also be noted that a modern teacher should have a high level of pedagogical and methodological competence regarding innovative educational technologies based on analytical and synthetic activity and creative approaches to their implementation. Innovative teaching methods, which rightfully include the essay, as it was mentioned above, are of double value, since, on the one 
hand, they are an effective form of vocational training, and on the other hand, they form an ability, methodological and practical readiness to apply such teaching methods in the future profession by their active application in the process of teaching educational disciplines, educational work.

Essays on social and pedagogical topics define the content for the student to perceive the future profession (as well as professional educational activity) as a significant component of the life and social space, associating their own social values with the professional ones, and thus perceiving the future professional activities as the basis for personal self-actualization. The existing high educational potential should be also taken into account, since the personality-oriented judgments determine the need for axiological measurements, self-analysis, self-determination within the problem, appealing to the personal qualities required to take the correct professional, social position.

The theoretical analysis of the problem and the results of investigational studies made it possible to determine the methodological validity for applying to the method of essays on social and pedagogical topics in the system of the teacher professional training, to highlight the priorities of its practical use. Integrally, the essay method:

- programs such a form and methodology for processing educational information, which provides for a high level of its comprehension, the ability to appropriately apply it in a context that is associated with the student's personality, life values and senses;

- is a form of combining the theory and practice, personality-oriented teaching methodology, in the context of which the theoretical material is perceived as significant information that forms the foundation for independent research work, the theoretical basis for both forming personal social and pedagogical projects, and providing valid justification, substantiation, the ability to independently prove the claimed viewpoints;

- contributes to the increase in the student's cognitive interest in educational activity, stimulates for its perception as an effective form of searching for answers to questions that are current, professionally and socially significant for a student;

- promotes self-actualization in the course of preparatory work and writing an essay, trying to focus on the problems that are the subject of their interest, informal spontaneous reflections and searching for answers to questions;

- contributes to the optimization of the methodology of developing the student's cognitive activity and its associativity by improving the ability to analyze educational information, interpret it, compare facts, construe own reflections based on theoretical foundations of the pedagogical science, integrating educational and social components, transforming the methods of reflection (analysis) for own life space. It fosters the possibility for non-standard (creative), unexpected interpretation of the educational material adapting it to the situation, content, filled with personal senses and priorities;

- promotes the development of the logic and speech culture, the search for personality-oriented models, style and forms for verbalizing their position, substantiation and persuasiveness of the conclusions drawn;

- has a high incentive regarding independent educational, self-educational activity and concerns the satisfaction of the need for knowledge (educational information) that lacked during comprehending the given problem;

- promotes the development of social and pedagogical competencies, personal qualities that are comprehended in an appropriate professional content and are the subject of self-awareness, selfdetermination, auto-evaluation, and etc.;

- brings in a variety of methods of educational activities, and thus provides a change in activities within an organized educational process, combining informational and reproductive, productive, interactive and creative teaching methods;

- provides multifunctionality of the educational process, since the essay can be a form of comprehending the educational material, elaborating the variants of its practical implementation, a form of self-determination regarding current problems, a form of controlling and assessing the level of competency development, indicating the existence of knowledge, its awareness, activity, readiness for creative use in problematic non-standard contexts and situations (fluency in the language of pedagogical theory);

-is a form of development of personality-oriented methodology and style of the future professional activity.

In general, the essay is a way to center on the issues that are of particular relevance in the process of professional development, living, which are the object of permanent searches both in the 
mode of organized learning activities and independent work with various sources of information, spontaneous communication with people, connected with a common problem.

In this context, we will analyze the content of essays or their elements, including those ones that have a long history and are still relevant.

We consider it expedient to show the philosophical nature of individual insights of various authors regarding the pedagogical problem that necessarily has a social context, and that is, as a rule, a fixed problem without a clear-cut answer and needs to be understood based on personal senses and current context, which also tend to vary on a permanent basis. Additionally, history shows that the problems that were subject to reflection by philosophers and educators in different historical epochs, have not lost their relevance to this day, especially at the stage of understanding the new educational competence-oriented paradigm.

J. Locke "On Education": "I tend to think that the knowledge we acquire in this world does not go beyond this life. Saving insight into another life does not require help of this dim twilight; but whatever it may be, I am sure that the main goal for which we must learn here is to use it for the sake of our prosperity and the welfare of others in this world. But if we lose our health, acquiring such knowledge, we work for the sake of things that will be of no use when we reach them; if, exhausting our bodies (though intending to make ourselves more active people), we lose the ability and opportunity to do the good work, which we are capable of with less talent, endowed by God, by denying us the power to improve this talent, which is available to people with a stronger body build, we greatly reduce our service to God and deprive our nearest and dearest of all the help that we, being in a healthy state, though with moderate knowledge, would be able to provide them. The one, who overloading their ship, though with gold, silver and precious jewels, sends it to the bottom, will present their master a bad report on their journey."

Priorities of the essay are provided through:

-interpretation of what is genuine (true) learning and its formalized variant, imitation (like going to school): the benefit or irrelevance of formal and actual learning;

- self-determination in relation to the true purpose of learning, its correlation with personal viewpoints, the dynamics of development in various educational systems (school, higher educational institution);

-reflection on the nature of education, its social value, significance for the person, interpretation of education in the context of human life space (pupil, student);

-balance of individual abilities, talents, potential of human development and standardized norms, volume and level of its acquisition, interpretation of the nature of the individual trajectory of the educational process;

- understanding the theory and basics of practical implementation of the learning differentiation principle, focusing on possible abilities of each individual;

-self-knowledge in order to determine the potential for professional, personal development of personality-oriented guidelines concerning the level and personalized method for their achievement;

-interpretation of the health-saving potential of learning, its relevance and methodological support.

V. Rozanov in "Fallen Leaves": "The everyday rule saying that children should respect their parents, and parents should love their children should be read conversely: these are parents who should respect their children, respect their unique small world and their passionate nature that is ready to take an offence at any moment; and children should only love their parents, and they will surely love them if they feel that respect to themselves."

Priorities of the essay are provided through:

- reflection on the problems of relationships between parents and children through the prism of classical behavior patterns presented in pedagogical literature;

- reflection on the problems of relationships between parents and children, using personal experience of family relationships, state of health, psychological comfort, conditions for selfactualization in their context;

- identification of problems that contribute a conflict to the relationship between children and parents, schools and parents, if to compare with classical patterns of behavior;

- determination of the fundamental nature of the concepts such as "respect" and "love", the mechanisms of their formation and interdependence in the pedagogical, social, and life continuum;

- designing the models for objectivation of the constructive system of relationships, providing them with theoretical substantiation by adapting to a real socially defined life situation. 
Social pedagogical essays may be formed based on the ideas, viewpoints, quotations, which provide for interpretation and methodological support regarding the internalization in personal practice (professional, social, life).

V. Sukhomlynsky: "The entire school life should be permeated with the spirit of humanity" [Vol. 4, p. 496]; "In the first place knowledge is needed to become a Man, a Citizen of your Motherland, an educated person, a creator, a father, a mother" [Vol. 5, p. 340]; "Teaching should have individualization: both in the content of mental labor (in the nature of tasks) and in time" [Vol. 2, p. 468]; "To educate the organic need for self-education, the desire to acquire knowledge life-long" [Vol. 4, p. 9]; "The pupil is not a passive object of teaching, but an active creative force, an active participant in the process of mastering knowledge" [Vol. 4, p. 214]; "To acquire knowledge means to discover the truth, cause-and-effect and other various connections" [Vol. 5, p. 366]; "We should put a vivid idea, the living word and creativity of the child into the basis of the education system" [Vol. 5, p. 340]; "The path from comprehending the facts, things, phenomena to deep understanding of an abstract truth (rules, formulas, law, words) lies through practical work that is precisely the mastering of knowledge" [Vol. 2, p. 456]; "In many children and adolescents, who are intelligent and gifted from birth, the interest in knowledge acquisition awakens only when their hand, tips of their fingers are included in creative work" [Vol. 2, p. 483]. Priorities of the essay are provided through:

- the ability to isolate from a given context a basic problem that determined the author's viewpoint, the ability to find it during real practical work and determine its relevance;

- correlation of their empirical representations about the problem, based on own experience of educational activity, revealing basic contradictions in its context and their substantiation;

- provision of a theoretical basis for interpreting the nature of the problem, mechanisms, patterns, principles that determine them, forming a model for the practical implementation of the viewpoint of the educator-scientist in a particular educational situation.

Conclusions. Thus, the methodological rationale for the essay is as follows: 1) it ensures transformation of the goal into the plan: development of teaching methods focusing on a specific intention (personality-oriented goal), which provides an opportunity to focus on aspects of the problem of a particular significance for the student in the process of professional development; 2) the technique of writing a creative work is worked out, directing it to a definite expected result from a problem that is burning for the student; 3 ) the method of work with theoretical material is optimized with the further formation of theoretical constructs, on the basis of which the work on its implementation into a practical plane on a personality-oriented basis is programmed; 4) increased level of efficiency of the methods of algorithm development for thinking activity in situation of theoretical and practical study of the problem, self-determination in its context; 5) the functions of the student's self-education, selfassessment activities are enhanced, which is manifested in the ability to make effective decisions regarding a pressing problem of both professional and social significance.

\section{REFERENCES}

1. H.L. Rudenko. Writing a Creative Essay. Master Klass [Workshop]. 2005. No. 3. P. 13-17.

2. V.O. Sukhomlynsky. Selected Works in Five Volumes. Kyiv, Soviet School Publ., 1976-1977.

3. Khamitov Nazip. Philosophy of the Man: From Metaphysics to Metaanthropology. Kyiv, Nika-Center Publ; Moscow, In-t of All Humanities Studies Publ, 2002. P. 77-82.

4. How to Write a Successful Essay: Guidelines for Essay Writing. Compiled by K.S. Shenderovsky. Institute of Mass communication at Taras Shevchenko Kyiv National University Publ. Kyiv, 2007, 34 p. 